\title{
THE LEGACY OF ALEPPINE OTTOMAN HOUSES
}

\author{
RAMI ALAFANDI \& ASIAH ABDUL RAHIM \\ Faculty of Architecture \& Environmental Design, International Islamic \\ University Malaysia, Kuala Lumpur, Malaysia.
}

\begin{abstract}
The objective of this article is to show the importance of the architectural and interior design of Aleppine houses. Aleppo is the second largest city in Syria (after the capital Damascus) and is also its commercial capital. Aleppo has a long history, extending from the third millennium B.C. to the Islamic era. Islamic rulers made Aleppo great by re-building its walls, gates, towers and citadel. The Muslims also built mosques, schools, houses, inns, markets, hospitals, bathrooms and public facilities. Consequently, Aleppo flourished and became a very important station on the Silk Road: the third largest city in the Ottoman Empire after Istanbul and Cairo. Aleppo was part of the Ottoman Empire from 1516 to 1918. As part of this empire, local Aleppine architects and craftsmen combined their techniques and cultural heritage with Ottoman architecture and design. Due to growth in population, the Ottomans expanded the city, provided facilities and established neighbourhoods outside the walls. These neighbourhoods outside the walls were mostly for the affluent and contained the greatest treasure of decoration and materials. This research employs a historical and descriptive approach to explore the history, design and decoration of the traditional houses during the Ottoman period. In 1986, UNESCO added Old Aleppo City to the World Heritage List. Since 2012 much of Syria's architectural heritage has been destroyed due to internal war. In Aleppo, the losses in both ancient and modern parts of the city have been tremendous. Some traditional houses have been damaged. This article will highlight some recommendations to protect and restore the traditional houses in Aleppo for future use.
\end{abstract}

Keywords: Aleppine houses, Aleppo City, Aleppo Heritage, Ottoman architecture.

\section{INTRODUCTION}

Ottoman style houses in Syria have become the icon of Ottoman Syrian art due to their unique design and decoration. The decorative art includes several geometric designs, floral motifs and inscriptions. These motifs have rich symbolic backgrounds, originating from house owners, artists, their native culture, the environment and religion. Impressive wooden interiors dating from the 17th to the 19th century have been preserved in Damascus, Aleppo and Hama (in Syria). This research will document the history of and describe the architecture and interiors of five houses in Aleppo.

\section{BACKGROUND RESEARCH}

\subsection{Aleppo's Heritage}

Aleppo is the largest city in Syria and serves as the capital of Aleppo Governorate (Fig. 1), the most populous Syrian governorate. It is located in northwest Syria, $310 \mathrm{~km}$ (193 miles) from Damascus. With an official population of 2,132,100 (2004 census), it is also one of the largest cities in the Levant. Consequently, Aleppo flourished as an important station on the Silk Road: the third largest city in the Ottoman Empire after Istanbul and Cairo [1]. 


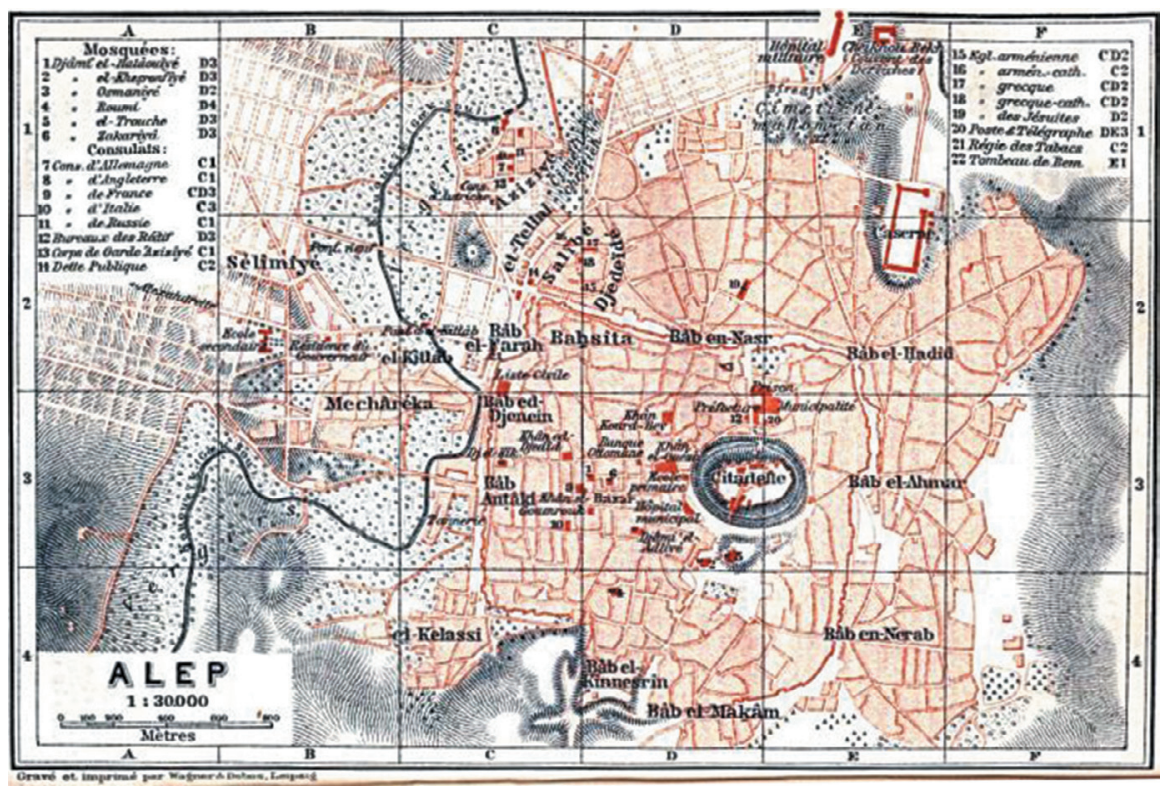

Figure 1: Aleppo map 1912 (wikipedia.org).

Aleppo is one of the oldest continuously inhabited cities in the world; it has been inhabited since perhaps as early as the 6th millennium B.C. Excavations at Tell as-Sawda and Tell alAnsari, just south of the Old City of Aleppo, show that the area was occupied by at least the latter part of the 3rd millennium B.C. Cuneiform tablets unearthed in Ebla and Mesopotamia noted Aleppo's commercial and military proficiency, due to its strategic trading point midway between the Mediterranean Sea and Mesopotamia [2].

The significance of the city in history has been its location at the end of the Silk Road, which passed through central Asia and Mesopotamia. When the Suez Canal was inaugurated in 1869, trade was diverted to the sea, and Aleppo began its slow decline. At the fall of the Ottoman Empire after World War I, Aleppo ceded its northern hinterland to modern Turkey, as well as the important railway connecting it to Mosul in Iraq. Then, in the 1940s, it lost its main access to the sea, Antioch and Alexandretta, also to Turkey. Finally, the isolation of Syria in the past few decades further exacerbated the situation. Possibly it is this very decline that has helped to preserve the Old City of Aleppo, its medieval architecture and traditional heritage. In 1986, UNESCO added Old Aleppo City to the World Heritage List [3]. In 2006, Aleppo won the title of the 'Islamic Capital of Culture 2006' and also witnessed a wave of successful restorations of its historic landmarks [4]. Since 2012 internal war has destroyed much of Syria's architectural heritage. The losses in both the ancient and modern parts of the city have been tremendous.

\subsection{Ottoman Houses in Aleppo}

Syrians always tried to make their houses like a heaven, and oriental design helped them [5]. The design of Aleppine house depends on the description of paradise found in the Quran:

But those who feared their Lord will be driven to Paradise in groups until, when they reach it while its gates have been opened and its keepers say, 'Peace be upon you; you have become pure; so enter it to abide eternally therein' [they will enter]. [6] 
Following is another description:

Those will have gardens of perpetual residence; beneath them rivers will flow. They will be adorned therein with bracelets of gold and will wear green garments of fine silk and brocade, reclining therein on adorned couches. Excellent is the reward, and good is the resting place [6].

Just as walls and gates surround Syrian cities, Aleppine houses also have walls and a gate, replicating the walls and gates of heaven. When walking through the alleys (Fig. 2), one sees only simple walls and doors. But, upon entering the gate through an indirect corridor, one will reach the courtyard, an earthly paradise, adorned with plants, trees and a water fountain [7]. The most important feature of the courtyard (Fig. 3) is the iwan, a room with an open wall facing the courtyard, sometimes as tall as two stories. The family prefers to sit here, with its open view of the courtyard and its moderate temperature, especially during the summer. Surrounding the courtyard are the ground floor rooms, selamlik, customized to receive men, and the upper rooms, haramlek, for private use of the family. All the rooms open onto the courtyard with large windows, which rarely face the outside [7]. The house also includes a kitchen, service rooms, a toilet and a cellar to preserve food. The house rarely includes a bath. Due to the importance of hospitality in Islamic and Arabic culture, guest rooms ( $\left.q a^{\prime} a\right)$ are more carefully decorated and furnished. Such rooms consist of one or three tazars (raised seating area of a room) and one 'ataba (low entry space of a room) [7]. Ottoman tazars, containing the largest treasure of polychrome wooden decorations ('ajami), have become the icon of Ottoman Syrian art. The 'ajami includes several geometric designs, floral motifs and inscriptions. These motifs have rich symbolic backgrounds, originating from house owners, artists, their native culture, the environment and religion. All traditional Aleppo houses are courtyard houses built of white limestone, whose colour changes over the years into light grey. The most obvious feature of the living quarters is the windowless and undecorated appearance of the house's outer facade, noted by almost all the travellers who visit Aleppo [8].

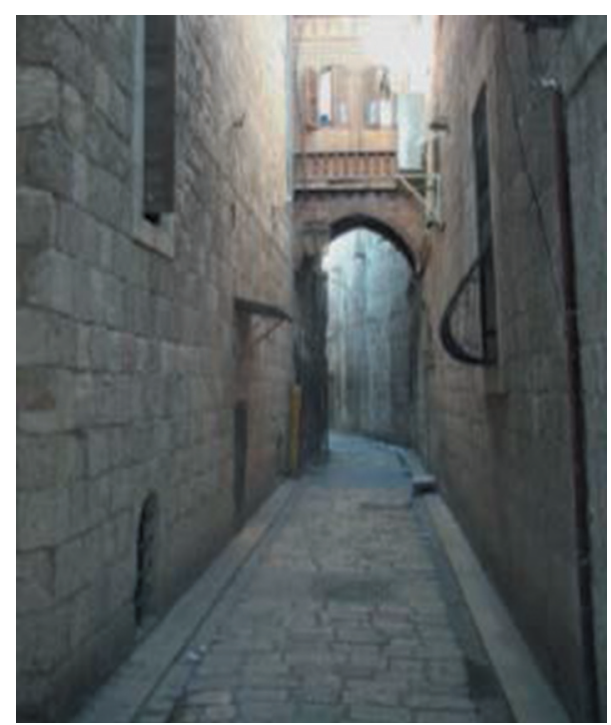

Figure 2: Alley, Old Aleppo City, Rami (2005). 


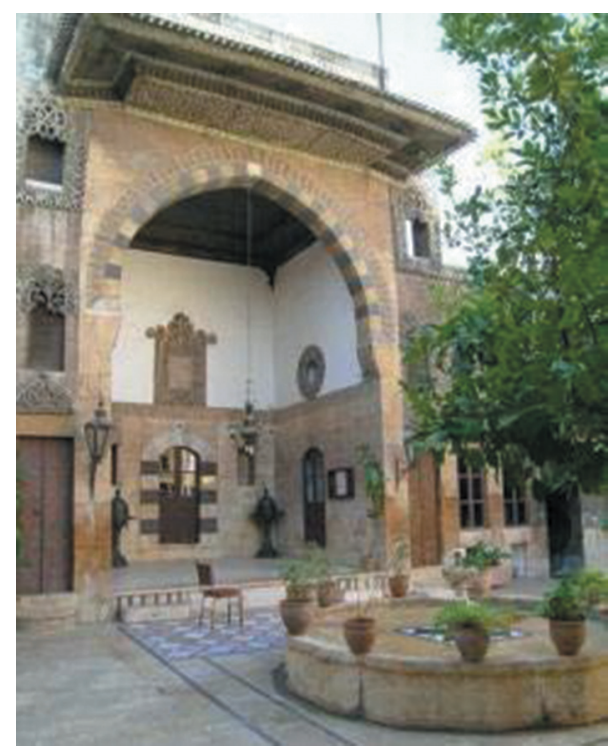

Figure 3: Courtyard, Ajek-Pash, Rami (2005).

\section{ALEPPINE HOUSES WITH DECORATION}

Houses of the Aljdayda district belong to the 16th and 17th centuries. They were the houses of the Aleppine bourgeoisie, who creatively decorated their houses. This article will focus on five houses (Ghazaleh, Kuba, Ajek-Pash, Zamria and Basil) that date back to the Ottoman period and have unique examples of 'ajami, which were documented in 2006 by the first author.

\subsection{Ghazaleh House}

This 17th-century building [9] is located in the extramural Aljdayda Quarter [10] and was built by Khajadour Bin Murad Bali in 1691 A.D./1102 A.H., as inscribed in the northern room ceiling (Fig. 4). Later, the Christian family Saba 'Aidaa lived in this house in 1737 A.D./1150 A.H. (Fig. 5), followed by the Ghazaleh family [11] (also Christian); there were more than 45 people living in the house in 1834 A.D./1250 A.H. (Fig. 6). In the early 20th century, the house was converted into a school for Arminians. By 2007, the Aleppo Antiquities and Museums Directorate refurbished the Ghazaleh House, transforming it into a historical museum for the City of Aleppo. In conjunction with this endeavour, from 2009 to 2011, they restored its 'ajami panels. In 2013, the 'ajami panels were stolen during the war in Old Aleppo City.

\subsubsection{Architectural descriptive}

The current plan of the house $\left(1,000 \mathrm{~m}^{2}\right)$ contains three courtyards surrounded by two levels of rooms (ground and upper floors) and underground facilities (Fig. 7): cellar and cave for preserving food, and the upper floor, haramlek, specified for women, which was built later. The size of the biggest courtyard, selamlik, is $260 \mathrm{~m}^{2}$ and has an iwan and qa'a. The second courtyard is $80 \mathrm{~m}^{2}$ and was used to supply food to the kitchen, while the third courtyard, of 


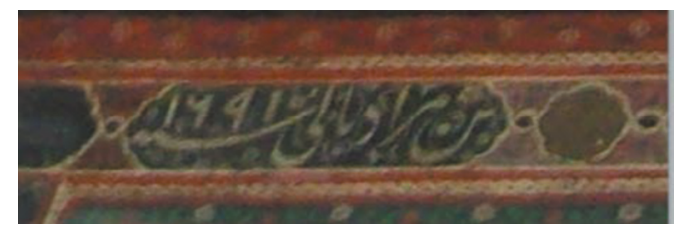

Figure 4: Northern room ceiling (1691 A.D./1102 A.H.), Rami (2006).

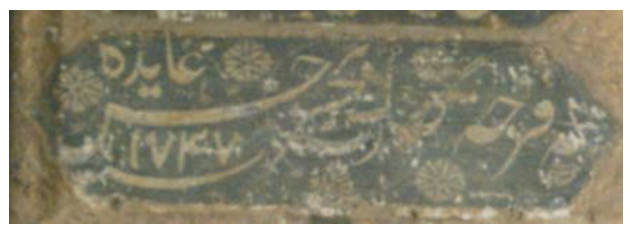

Figure 5: $Q a^{\prime} a$ wall (1737 A.D./1150 A.H.), Rami (2006).

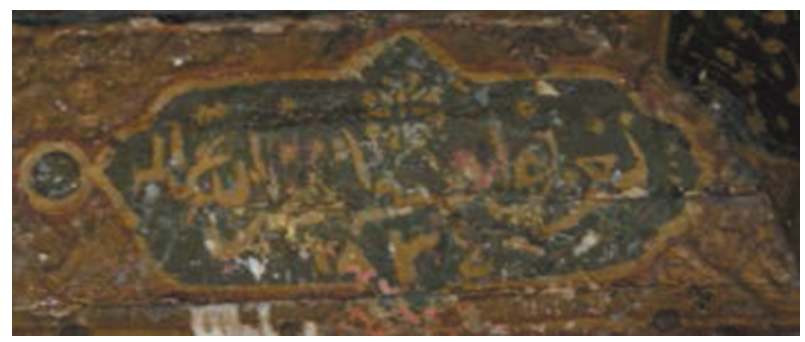

Figure 6: Northern room wall cornice (1834 A.D./1250 A.H.), Rami (2006).

$25 \mathrm{~m}^{2}$, was used to service the bathhouse. Ghazaleh House is the only house in Old Aleppo City which has a bath.

The qa' $a$ consists of three tazars with one 'ataba forming the shape of the letter ' $T$ '. All nine walls and three ceilings have 'ajami panels with floral and geometrical motifs and inscriptions of poetry and proverbs. There is a fountain in the centre of the 'ataba. The iwan is located in the south part of the main courtyard. It has an 'ajami ceiling with cornice. The northern hall is a rectangular room; the walls and ceilings are covered by 'ajami panels which are dated by the names of the owners.

\subsection{Kuba House}

Located near Farhat Square in the Aljdayda Quarter, Kuba House was built in 1718 A.D./1130 A.H., according to the inscription in 'ajami on the ceiling of the upper room (Fig. 8). The owner was Fateh-Allah Kuba [12] and, in 2004, this house was left by the inheritor who emigrated to America.

\subsubsection{Architectural descriptive}

The house contains four levels: the ground, two upper floors and the underground floor, which has a cellar and cave. The courtyard is surrounded by an iwan with three rooms for 


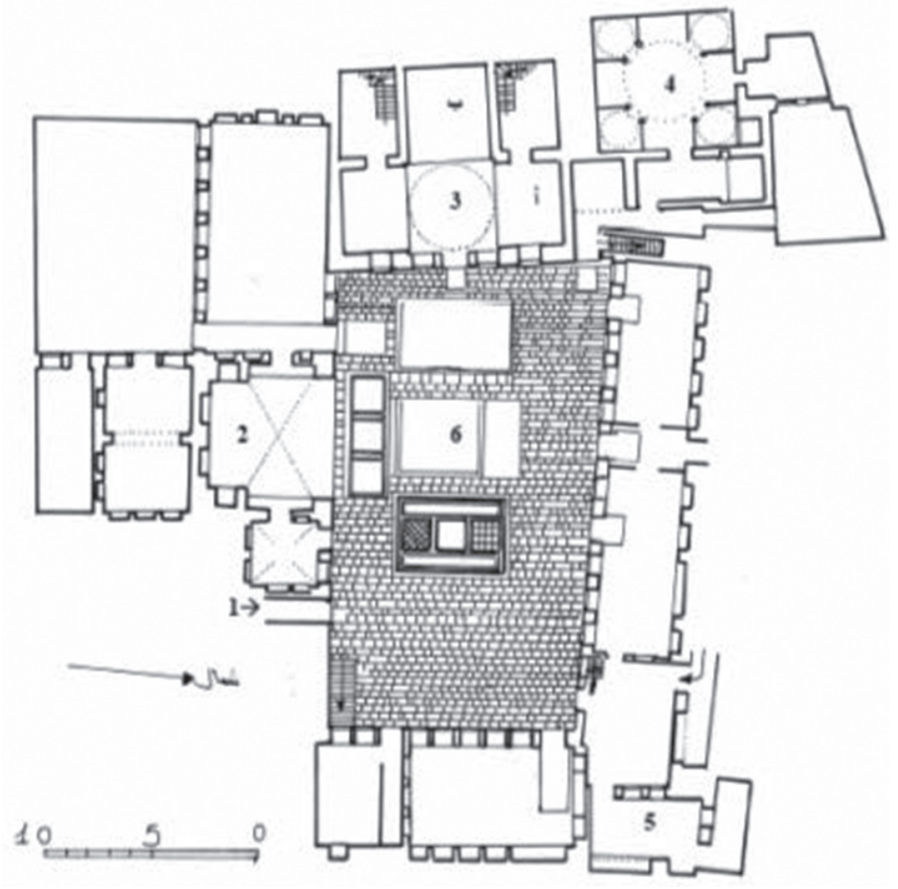

Figure 7: Ghazaleh plan, Burabeh [14].

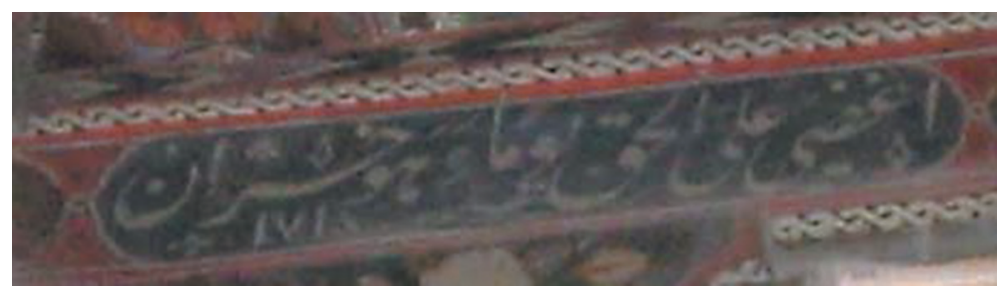

Figure 8: Inscription date, Rami (2006).

selamlik, service rooms, a kitchen and facilities (Fig. 9). On the upper floor are the haramlek and the mezzanine floor is for the maids. There is a fabulous marble fountain in the courtyard, the $i w a n$ has a sunshade made of 'ajami panels and the guest room is decorated by 'ajami on the walls and ceiling. Also, there is one room in the upper floor which has an 'ajami ceiling.

\subsection{Ajek-Pash House}

Located near the Jasmine gate in the Aljdayda Quarter, according to the inscription (Fig. 10), this house was built in 1757 A.D./1171 A.H. by the grandfather of Yousef-Karaly [12] (also known as Ajek-Pash). Later the Syriac Catholic Church owned the house and used it as a hostel for the poor. In 1967, the Aleppo Antiquities and Museums Directorate transformed it into a traditional museum for Aleppo City. In 2013, the polychrome wooden panels were stolen during the war in Old Aleppo City. 


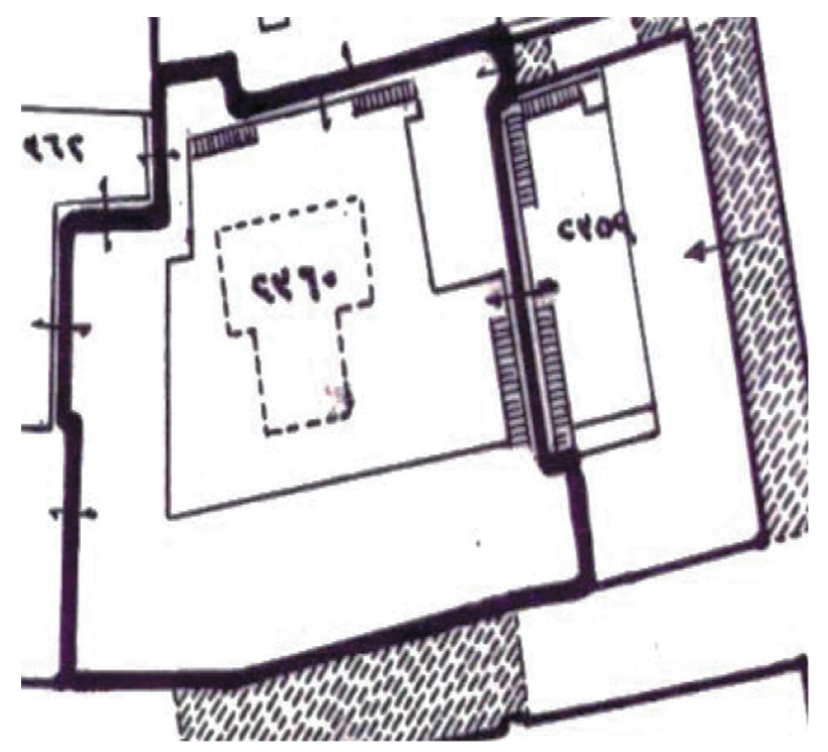

Figure 9: Kuba plan, Burabeh [14].

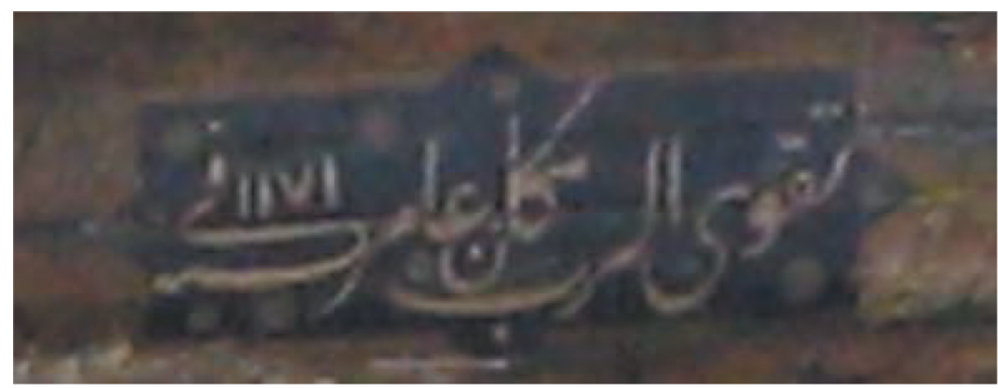

Figure 10: Inscription date, Rami (2006).

\subsubsection{Architectural descriptive}

The house contains five levels: the ground, mezzanine, an upper floor and the underground floor which has the cellar and cave with cistern. The courtyard (Fig. 11) is surrounded by an iwan with four rooms for selamlik, which also hold the kitchen and facilities. On the upper floor are the rooms for haramlek. European influence is evident in this house, as are many houses in Aleppo in the 18th century; the windows are framed with carved stone of baroque and rococo styles. The qa' $a$ is a rectangular space with one tazar and an 'ataba decorated by ornate 'ajami panels on the ceiling and walls (Fig. 12). The other three rooms on ground floor and $i w a n$ are also adorned with 'ajami panels.

\subsection{Zamria House}

This is located in the Aljdayda Quarter and was built in 1733 A.D./1145 A.H. [13] by Khazdar Osmani [14]. In 1808 A.D./1223 A.H., the Zamria family owned the house (Fig. 13). In 1997, Martini Co. converted the house into a traditional hotel and restaurant [14]. During the internal war in Syria (2012-2013), Zamria House was shelled many times, and the house was partly damaged, then completely burnt and many parts were destroyed. 


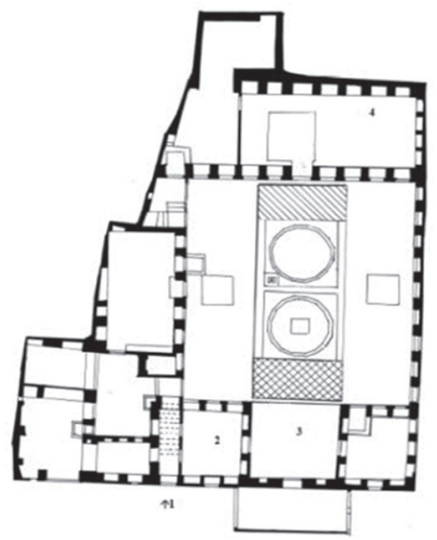

Figure 11: Ajek-Pash plan, Burabeh [14].

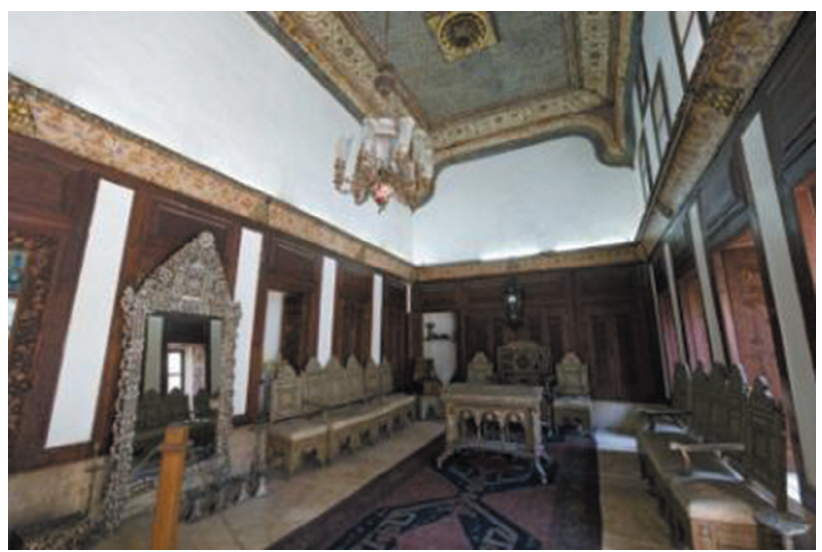

Figure 12: $Q a^{\prime} a$ of Ajek-Pash, Rami (2006).

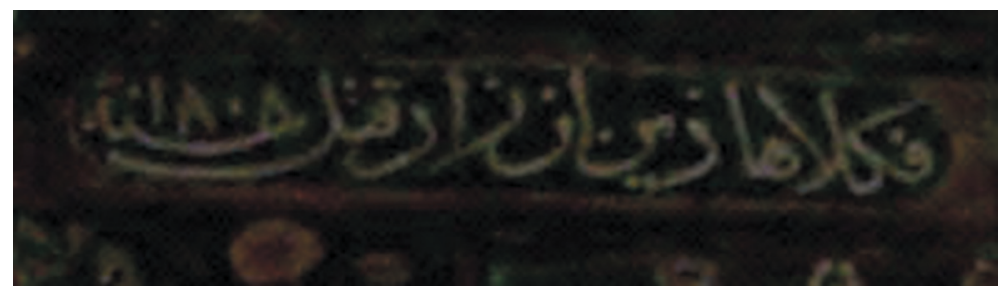

Figure 13: Inscription date, Rami (2006).

\subsubsection{Architectural descriptive}

The house contains two levels: the ground floor and the underground floor, which has the cellar and cave with a cistern. The courtyard is square with a small fountain and is surrounded by an iwan (Fig. 14) and two rooms with qa'a. The room on the right of the iwan is for selamlik, and the one on the left is for haramlek (Fig. 15). The ground floor also contains a kitchen and facilities (Fig. 16). 


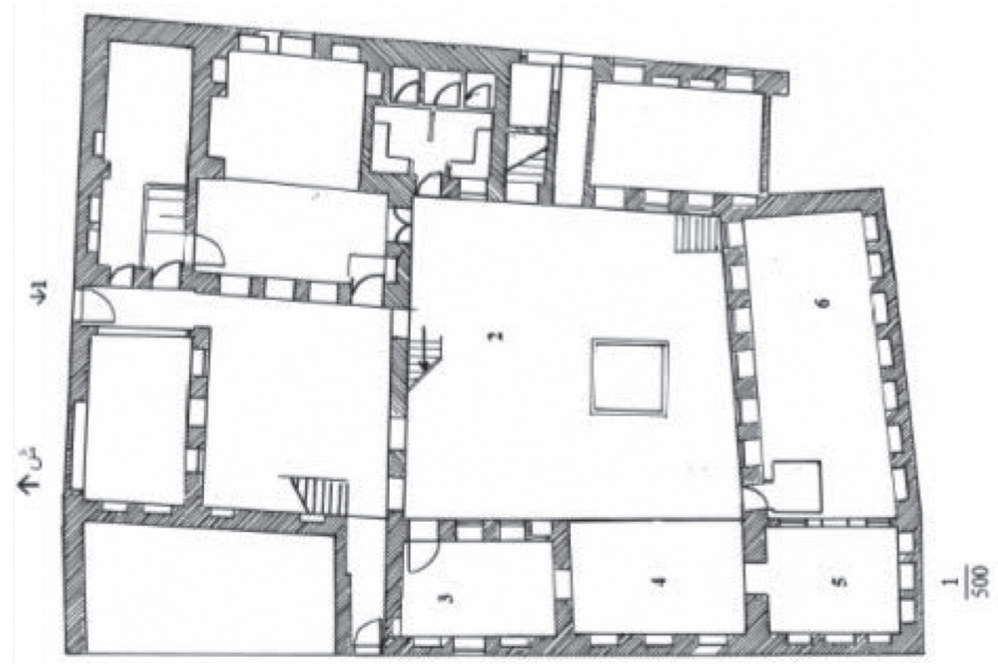

Figure 14: Zamria plan, Burabeh [14].

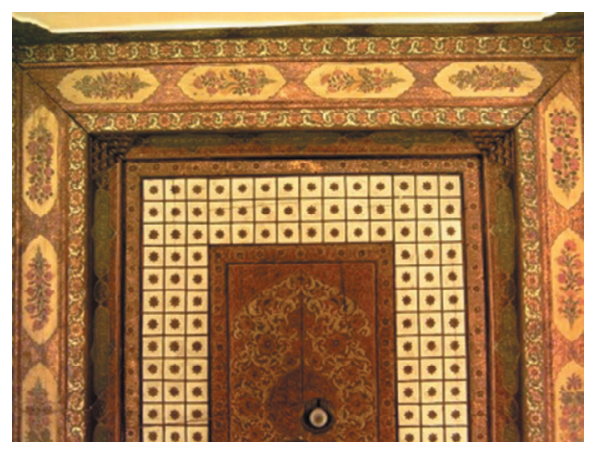

Figure 15: Haramlek ceiling, Rami (2006).

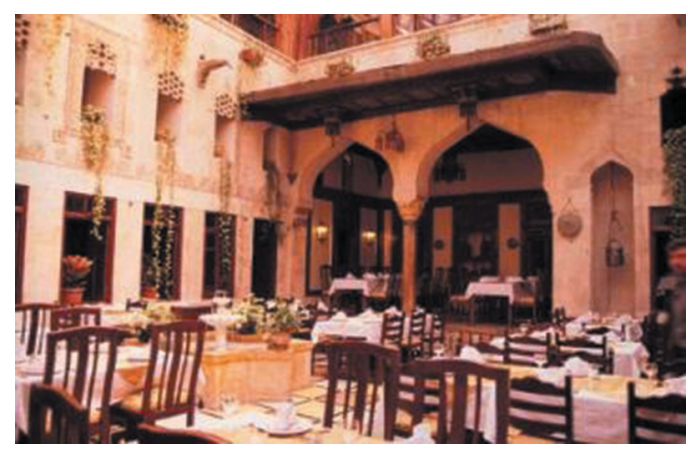

Figure 16: Zamria courtyard, Rami (2006). 
The $q a$ ' $a$ is a rectangular space without an 'ataba and is decorated with 'ajami panels on the ceiling and walls. The iwan's ceiling and walls are decorated with 'ajami panels with a sunshade; it also has two rooms and a qa'a.

\subsection{Basil House}

This building is located in Bahira Monk lane in Aljdayda quarter and, according to the inscription on its 'ajami, the house was built early in 1772 A.D./1186 A.H. and was decorated in 1785 A.D./1199 A.H. (Fig. 17) by the Basil family [14]. In 2002, the house was converted into an institute for languages and art [14].

\subsubsection{Architectural descriptive}

The house comprises three levels: the ground floor, the upper floor, and the underground floor, which contains the cellar. The courtyard is square with a fountain (Fig. 18) and is surrounded by an iwan, four selamlik rooms, a qa' $a$ and a kitchen and facilities (Fig. 19). The upper floor contains haramlek rooms.

The qa' $a$ consists of three tazars with an 'ataba forming the shape of a 'T'. All nine walls and three ceilings have 'ajami panels with floral and geometrical motifs, and inscriptions of

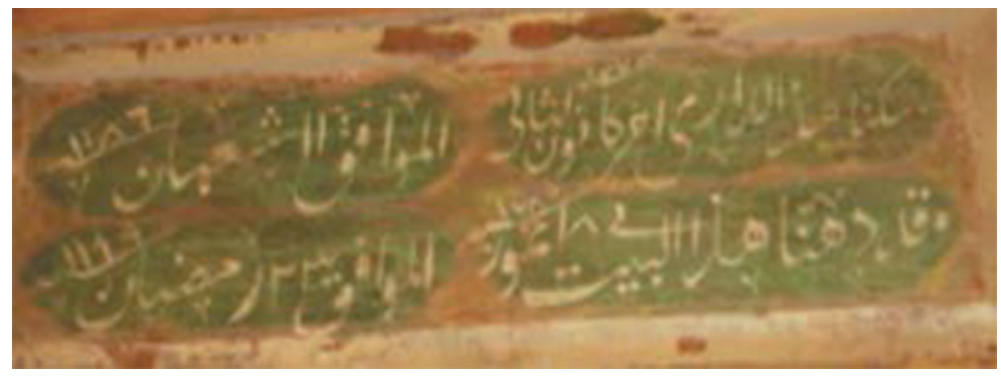

Figure 17: Inscription date, Rami (2006).

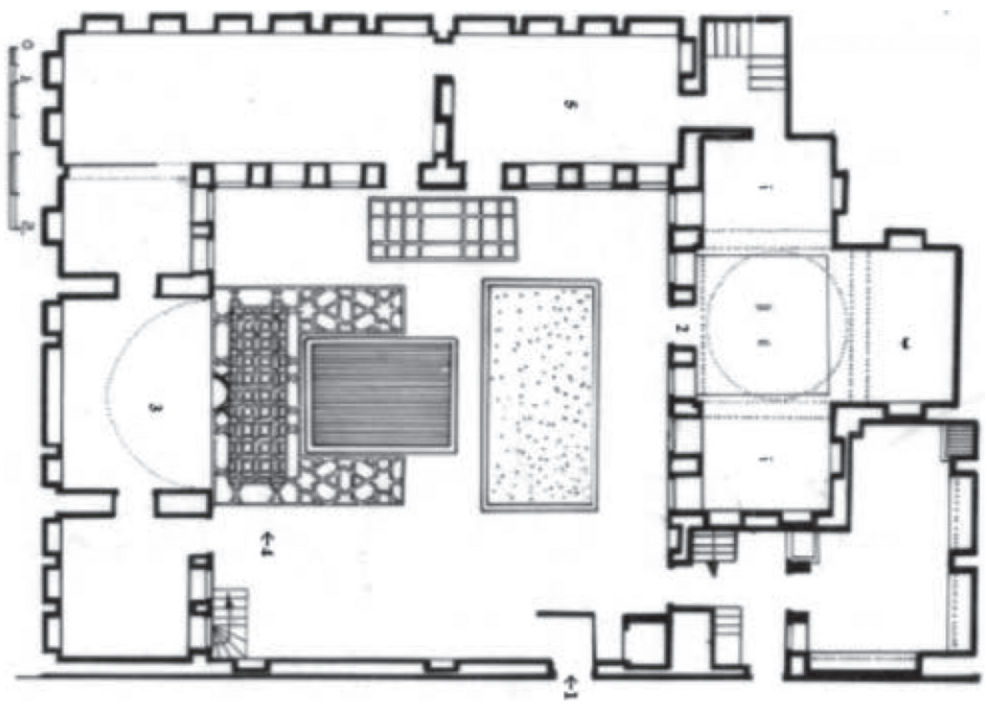

Figure 18: Basil plan, Burabeh [14]. 
120 Islamic Heritage Architecture

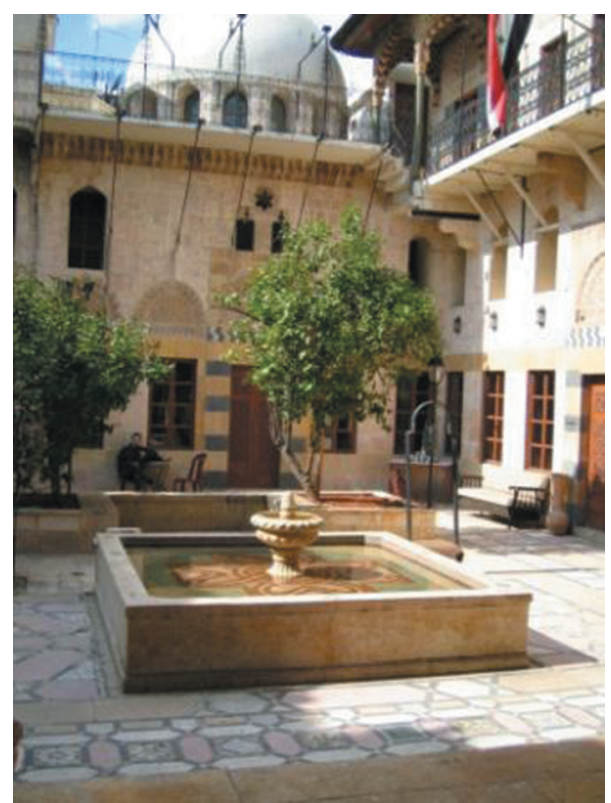

Figure 19: Basil courtyard, Rami (2006).

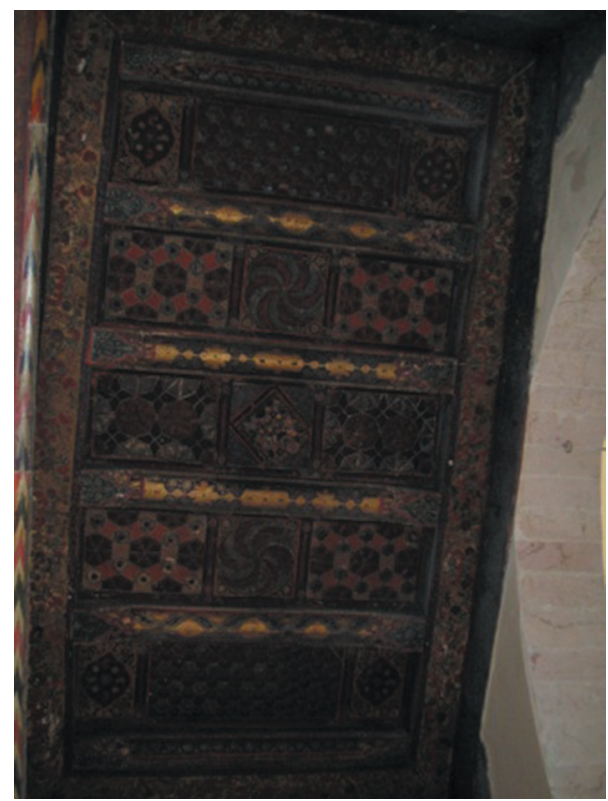

Figure 20: One of the $q a^{\prime}$ a ceiling, Rami (2006). 
poetry and proverbs (Fig. 20). The ceiling and walls of the iwan and its sunshade, the four rooms, and the $q a^{\prime} a$ are adorned with 'ajami panels.

\section{ANALYSIS AND RECOMMENDATIONS}

- The five houses studied are dated by the 'ajami panels. The oldest is the Ghazaleh House (1691 A.D./1102 A.H.), then Kuba (1718 A.D./1130 A.H.), Zamria (1733 A.D./1145 A.H.), Ajek-Pash (1757 A.D./1171 A.H.) and finally Basil (1772 A.D./1186 A.H.).

- Ghazaleh and Basil are the only houses with triple qa'a (the qa'a with three tazars).

- The artist who applied the decorations to the wood and stones was influenced by the environment of the Middle East, whose artists used local floral motifs on the wood. Some of these motifs did not originate in Syria but came to the Middle East via the Silk Road from Asia and Europe. The Ottomans adopted, developed and used some motifs which came from Europe. Ottoman art and architecture were also directly impacted by Rococo and Baroque styles from Europe.

- The Ottomans synthesized all the previous skills and knowledge of craftsmen and artists from the Islamic world and other cultures. The geometrical motifs developed through the Islamic civilization and Ottoman art were the culmination of the development of the geometrical Islamic art.

- The inscriptions on the 'ajami panels indicated that the owners were intellectuals or at least sufficiently well educated to use poetry, wisdom and proverbs in the inscriptions to entertain their guests.

- Whether the owner was Muslim or Christian, there are no differences in the design or the decorations, especially in the houses studied above.

- The 'ajami panels were destroyed in Zamria House and stolen from Ghazaleh and AjekPash Houses. The efforts to restore and renovate them cannot succeed unless the fighting stops. However, some efforts have been made even in dangerous situations. In the meantime, a plan for restoration and renovation can be prepared. This requires doing the following:

- Approximate monitoring of all the physical, social and economic damage. To estimate the cost of the restoration and renovation.

- Determine who will finance this project and how much funding will be needed.

- Find competent consultants and experts who will participate.

- Learn from previous local and global experience.

\section{CONCLUSION}

This study is one of the very few studies which have investigated Aleppine houses, particularly their decoration, which has been eroded and in some cases destroyed, especially in the last three years during Syria's internal war. These designs and the decoration of Aleppine houses not only show the owner's aesthetic taste but also represent the evolution of Islamic art and architecture during the Ottoman rule in Syria. The documentation of the houses in this study can be helpful to restore the damaged houses. 


\section{REFERENCES}

[1] Alafandi, Rami \& Abdul Rahim, Asiah, Umayyad Mosque in Aleppo. Yesterday, today, and tomorrow. International Journal of Art \& Sciences Conference, Harvard Campus: Boston, 2014.

[2] Russell, Alexander. The Natural History of Aleppo, 1st ed., G.G. and J. Robinson: London. p. 266, 1794.

[3] http://www.worldheritagesite.org/sites/aleppo.html, 2013

[4] http://en.wikipedia.org/wiki/Aleppo, 2015

[5] Gunay, Reha, Tradition of the Turkish House and Safranbolu Houses, YEM Yayin: Istanbul, Turkey, p. 62, 1998.

[6] The Holy Qurn, Surat Az-Zumar:73, Surat Al-Kahf:31.

[7] Alafandi, Rami \& Abdul Rahim, Asiah, Syrian Palaces in Ottoman Style, ICABE: Malaysia. p. 4, 2013.

[8] Mollenhauer, Anne \& Karzon, Zouka, A Survey of Manorial Residential Houses in the Bab Qinnasrin Quarter of Aleppo. In: Chronos, Revue d'Histoire de l'Université de Balamand, Vol. 4, 2001.

[9] Sauvaget ,Jean, Alep, essai sur le développement d'une grands ville svrienne des origines au milieu du XIX siécle, P. Geuthner: Paris, p. 51, 1941.

[10] Hajar, Abdullah, Aleppo Monuments. Aleppo University: Aleppo, p. 121, 1998.

[11] Algazi, Kamel, Gold River in History of Aleppo. Aleppo. Dar Alqalam Alarabi, Vol. 2, p. 203, 1991.

[12] De Sallé, Eusébe, Pérégrinations en Orient ou vcvage pittoresque Historique et politique en Egypte Nubie, Syrie, Turquie, pendant les années 18371838 1839. Paris Pagnerre \& Curmer. Paris. pp. 112, 115, 1840.

[13] David, Jean-Claude, Alep. dégadations et tentaives actuelles de réadaptation des structures urbaines traditionnelles. Bulletin d'études orientales, XXVIII, p. 23, 1975.

[14] Burabeh, Latifa, Illustration of Ceilings in Civilian Buildings during Ottoman Empire in Algeria, Aleppo and Damascus Cities, Algeria University: Algeria, p. 24, 2009. 